\title{
Yield, chemical composition and chlorophyll relative content of Tanzania and Mombaça grasses irrigated and fertilized with nitrogen after corn intercropping ${ }^{1}$
}

\author{
Cristiano Magalhães Pariz², Marcelo Andreotti², Antonio Fernando Bergamaschine ${ }^{2}$, \\ Salatiér Buzetti ${ }^{2}$, Nídia Raquel Costa ${ }^{2}$, Maria Cecilia Cavallini ${ }^{2}$, Nelson de Araújo Ulian², \\ Fabiana Golin Luiggi ${ }^{3}$
}

1 Projeto financiado pela CAPES.

2 Universidade Estadual Paulista "Júlio de Mesquita Filho", Faculdade de Engenharia, Caixa Postal 31, 15385-000, Ilha Solteira, SP, Brasil.

${ }^{3}$ Universidade Estadual Paulista "Júlio de Mesquita Filho", Faculdade de Medicina Veterinária e Zootecnia, Botucatu, SP, Brasil.

ABSTRACT - It was evaluated the effect of the absence and of application of three nitrogen doses (50, 100 and $200 \mathrm{~kg} \mathrm{ha}^{-1}$ of $\mathrm{N}$ ) and four harvest times in the winter/spring season (from July to October) on dry mass yield (DMY), on the relative chlorophyll contents (ICF - leaf chlorophyll index) and on the contents of total digestible nutrients (TDN), crude protein (CP), neutral detergent fiber (NDF), acid detergent fiber (ADF) and lignin, and their respective correlations on Tanzania and Mombaça grasses after intercrop with corn in distroferric red latosol (Oxisol) soil as well. It was used a random block design, in split-plot with four replicates. The greatest DMY occured with the increase of photoperiod (from August), neverthless responses to nitrogen fertilization over cuts difered among the grasses. In an irrigated crop-livestock integration system under cerrado conditions, it is technically feasible the establishment of Tanzania and Mombaça grass intercroped with corn at sowing or if cover nitrogen fertilization is performed because even in the abscence of nitrogen fertilization, great satisfactory quantity of forage was produced, with average DMY of 2,000 kg ha-1 per cut during the highest shortage of roughage for animals (winter/spring). Nitrogen fertilization after corn harvest increases DMY and improves bromatologic composition of the grasses, as contents of chlorophyll and CP in winter/spring is increased, besides the increase of contents of TDN and a reduction on the contents of NDF and ADF until September. Leaf chlorophyll index can be used to estimate the DMY and CP content and as a marker of the need of nitrogen fertilization of Tanzania and Mombaça grasses submitted to cutting.

Key Words: crop-livestock integration, crude protein, Megathyrsus maximum, neutral and acid detergent fiber, no-tillage system, total digestible nutrients

\section{Produtividade, composição bromatológica e teor relativo de clorofila dos capins tanzânia e mombaça irrigados e adubados com nitrogênio após o consórcio com milho}

RESUMO - Avaliou-se o efeito da ausência e da aplicação de três doses de nitrogênio (50, 100 e $200 \mathrm{~kg} \mathrm{ha}^{-1}$ de N) e quatro épocas de corte no inverno/primavera (julho a outubro) sobre a produtividade de massa seca (PMS), os teores relativos de clorofila (ICF - índice de clorofila foliar) e os teores de nutrientes digestíveis totais (NDT), proteína bruta (PB), fibra em detergente neutro (FDN), fibra em detergente ácido (FDA) e lignina, bem como suas respectivas correlações nos capins tanzânia e mombaça após o consórcio com milho em um Latossolo Vermelho distroférrico. O delineamento experimental utilizado foi o de blocos casualizados, em parcelas subdivididas, com quatro repetições. As maiores PMS ocorreram com o aumento do fotoperíodo (a partir de agosto), no entanto, as respostas à adubação nitrogenada ao longo dos cortes diferiram entre e dentre os capins. Em sistema de integração lavoura-pecuária irrigado sob condições de cerrado, é tecnicamente viável o estabelecimento dos capins tanzânia e mombaça em consórcio com o milho no momento da semeadura ou por ocasião da adubação nitrogenada de cobertura, visto que, mesmo na ausência de adubação nitrogenada, foi produzida quantidade satisfatória de forragem, com PMS média de $2.000 \mathrm{~kg} \mathrm{ha}^{-1}$ por corte na época de maior escassez de volumoso para os animais (inverno/primavera). A adubação nitrogenada após a colheita do milho eleva a PMS e melhora a composição bromatológica dos capins, com aumento dos teores relativos de clorofila e PB no inverno/primavera, além de aumento dos teores de NDT e redução dos teores de FDN e FDA até o mês de setembro. O índice de clorofila foliar pode ser utilizado para estimar a PMS e o teor de PB, bem como indicar a necessidade de adubação nitrogenada dos capins tanzânia e mombaça submetidos a corte.

Palavras-chave: fibra em detergente neutro e ácido, integração lavoura-pecuária, Megathyrsus maximum, nutrientes digestíveis totais, proteína bruta, sistema plantio direto 


\section{Introduction}

The use of agricultural areas throughout the year is possible because of crop-livestock integration in no-till farming, involving the cultivation of grain crops and livestock production, with positive socio-economic and environmental results (Kluthcouski \& Yokoyama, 2003; Tracy \& Zhang, 2008).

According to Aidar et al. (2003), in the Brazilian cerrados, the cultivation of grain crops in autumn (offseason) may be rendered non-viable mainly because of water deficits. Therefore, the intercropping of corn with perennial forages (Megathyrsus and Urochloa) in the summer is an option for the production of forage from autumn to spring (Kluthcouski \& Yokoyama, 2003), when the harvesting of grasses to provide animal forage is an alternative to storing them in the form of silage.

Benefits resulting from the residual effect, mainly from phosphate and potassium fertilization in the crop-livestock integration, are described by Martha Júnior \& Vilela (2007). However, these authors point out that in the course of crop succession and/or rotation, the lack of nitrogen fertilization of the pasture may compromise the system. Nevertheless because of the unfavorable climatic conditions, Barducci et al. (2009) did not verify the response of Mombaça grass to nitrogen fertilization from autumn to spring after the simultaneous intercropping with corn. Therefore, more studies are required to evaluate the use and viability of this grass in crop-livestock integration systems inasmuch as in addition to the greater competition by corn, there is the seasonality of growth until the start of spring and the formation of tussocks hampers desiccation and the sowing of the subsequent crop.

The determination of the relative chlorophyll content in the leaf blades by using a SPAD (Soil Plant Analysis Development) or ICF (leaf chlorophyll index), generally correlates with the $\mathrm{N}$ content, enabling a prior diagnosis of a possible deficiency of the nutrient (Rocha et al., 2005). However, there are still very few works correlating these indexes with the chemical composition and the productivity of tropical perennial grass pastures managed in crop-livestock integration systems. The objective of this work was to evaluate the dry mass yield (DMY) and the chemical composition of M. maximum cv. Tanzania and Mombaça grass fertilized with $\mathrm{N}$ and subjected to harvesting in winter/ spring following the intercropping with corn, as well as to analyze the correlation of the ICF with the DMY and total digestible nutrients (TDN), crude protein (CP), neutral (NDF) and acid detergent fiber (ADF), and lignin contents.

\section{Material and Methods}

The experiment was carried out from 2007 to 2008, at the Fazenda de Ensino, Pesquisa e Extensão (FEPE), belonging to the Faculdade de Engenharia, Campus of Ilha Solteira (FE/Unesp), an area of vegetal production, located in the municipality of Selvíria, state of Mato Grosso do Sul

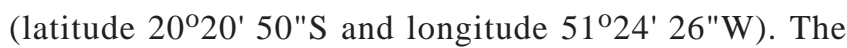
climatic type is Aw, according to the Köppen classification, characterized as humid tropical with wet season in the summer (October to April) and dry season in the winter (May to September) (Figure 1).

The soil in the area is a distroferric Red Latosol (Embrapa, 2006). Before setting up the experiment in the 0 to $0.20 \mathrm{~m}$ layer of the soil, the physical and chemical attributes were: soil density $=1.31 \mathrm{~kg} \mathrm{dm}^{-3}$; macro, micro and total porosity $=0.147 ; 0.334$ and $0.481 \mathrm{~m}^{3} \mathrm{~m}^{-3}$, respectively; $\mathrm{pH}\left(\mathrm{CaCl}_{2}\right)=5.1$; organic matter $(\mathrm{OM})=28 \mathrm{~g} \mathrm{dm}^{-3} ; \mathrm{H}+\mathrm{Al}=$ $22.2 \mathrm{mmol}_{\mathrm{C}} \mathrm{dm}^{-3} ; \mathrm{P}($ resin $)=18 \mathrm{mg} \mathrm{dm}^{-3} ; \mathrm{K}^{+}, \mathrm{Ca}^{2+}$ and $\mathrm{Mg}^{2+}=3.2 ; 19.0$ and $11.0 \mathrm{mmol}_{\mathrm{C}} \mathrm{dm}^{-3}$, respectively, and base saturation of the soil $(\mathrm{V})=59.9$ per cent. The experimental area had a history of five years under notillage system in initial/transition phase with corn crops

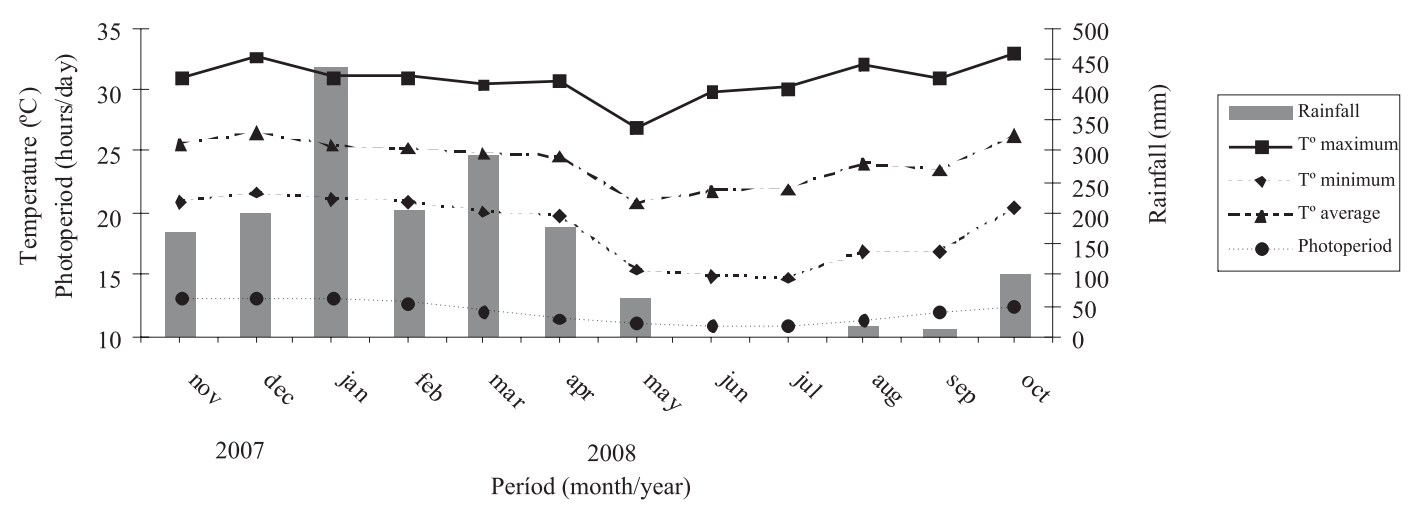

Figure 1 - Climatic data. 
(Zea mays L.), soybean (Glycine max (L.) Merr), forage sorghum (Sorghum bicolor (L.) Moench), pigeon pea (Cajanus cajan (L.) Millsp), Urochloa brizantha cv. palisade grass and beans (Phaseolus vulgaris L.). The area was irrigated by a central pivot, when necessary because of water deficits throughout the entire experimental period.

It was used a randomized block experimental design subdivided into plots, with four replicates. The plots received four types of treatment (intercropping) of the grasses with corn in the 2007/2008 cropping season: TS - M. maximum cv. Tanzania (Tanzania grass) planted simultaneously; TC - M. maximum cv. Tanzania (Tanzania grass) planted at the time of cover nitrogen fertilization; MS - M. maximum cv. Mombaça (Mombaça grass) planted simultaneously; MC M. maximum cv. Mombaça (Mombaça grass) planted at the time of cover nitrogen fertilization, and in the sub-plots, the absence of nitrogen fertilization and the doses of nitrogen applied to the grasses (50, 100 and $200 \mathrm{~kg} \mathrm{ha}^{-1}$ of N), after each of the four harvest times in the winter/spring. The plots measured $90 \mathrm{~m}^{2}$ and the subplots had $18 \mathrm{~m}^{2}$ of useful area. The simple corn hybrid AG 8088 (early cycle) was sown in rows spaced by $0.90 \mathrm{~m}$ for grain production. The starter fertilizer consisted of an application of $20 \mathrm{~kg} \mathrm{ha}^{-1}$ of $\mathrm{N}, 70 \mathrm{~kg} \mathrm{ha}^{-1}$ of $\mathrm{P}_{2} \mathrm{O}_{5}$ and $40 \mathrm{~kg} \mathrm{ha}^{-1}$ of $\mathrm{K}_{2} \mathrm{O}(250 \mathrm{~kg}$ of the fertilizer formulated 08-28-16 per ha) and the mineral fertilizer cover consisted of the application of $100 \mathrm{~kg} \mathrm{ha}^{-1}$ of $\mathrm{N}$ (urea -45 per cent of $\mathrm{N}$ ).

The grasses were sown in the corn inter-lines with a spacing of $0.34 \mathrm{~m}$ at a quantity of $7 \mathrm{~kg} \mathrm{ha}^{-1}$ of seeds (cultural value $=76 \%$ ), with the plots where the grasses were sown in simultaneously with the corn (11/20/2007). The operation was mechanized using another seeding-fertilizer machine for no-tillage system, while in the plots in which the grasses were sown together with the cover nitrogen fertilization of the corn (12/19/2007), the seeds were mixed with the fertilizer shortly before sowing and placed in the fertilizer compartment of the seeding-fertilizer machine. In all the intercrops, the seeds of the grasses were deposited in the soil at a depth of $0.03 \mathrm{~m}$. On December $17^{\text {th }} 2007$, Nicosulfuron ${ }^{\circledR}$ herbicide was applied (8 $\mathrm{g}$ of active ingredient/ha) to reduce the growth of the grasses sown simultaneously with the corn.

The harvesting of the corn occurred on April $25^{\text {th }} 2008$ and on June $10^{\text {th }} 2008$, the experimental units were evenly trimmed with a rotary mower, adopting as reference $0.25 \mathrm{~m}$ in relation to the ground surface, in order to stimulate the profiling and standardize the phenological age of the grasses without removing the material from the area, with the straw remaining on the surface of the ground. After that, applications of doses of $\mathrm{N}$ (urea) in side-dressing were distributed in the inter-lines of the grasses, with the first application on June $30^{\text {th }} 2008$. Harvesting occurred on July $30^{\text {th }} 2008$, August $29^{\text {th }} 2008$, September $29^{\text {th }} 2008$ and October $29^{\text {th }} 2008\left(1^{\text {st }}, 2^{\text {nd }}, 3^{\text {rd }}\right.$ and $4^{\text {th }}$ periods, respectively $)$ and applications of fertilizer were carried out immediately after the trimming of the grasses by using a rotary mower at a height of $0.40 \mathrm{~m}$ in relation to the ground surface with subsequent removal of the material, in which mainly leaves were exported from the area. Before mechanical harvest, at this same height, for the purposes of sampling, $0.25 \mathrm{~m}^{2}$ of the subplot was collected with the aid of a metal square, in order to determine the dry mass yield (DMY) (oven-dried at $65^{\circ} \mathrm{C}$ until constant mass) and laboratory analyses were carried out to determine crude protein (CP), neutral detergent fiber (NDF), acid detergent fiber (ADF) and lignin contents according to the methodology by Silva \& Queiroz (2002), and total digestible nutrients (TDN) contents, according to the methodology by Cappelle et al. (2001).

The determination of the relative foliar chlorophyll content was carried at grass harvest by using a digital chlorophyll meter (CFL 1030 - Falker) for leaf chlorophyll index (ICF) readings on the middle third of the blade of recently opened leaves (Manarim \& Monteiro, 2003; Lavres Júnior \& Monteiro, 2006), totaling an average of five readings per subplot.

The data were subjected to analysis of variance (test $\mathrm{F}$ ) and the doses of nitrogen adjusted by regression analysis (orthogonal polynomials), adopting the highest $\mathrm{R}^{2}(\mathrm{p} \leq 0.05)$ and in the case of no significance, the means of the intercrops and the times of harvesting were compared by the Tukey test $(\mathrm{p} \leq 0.05)$. The statistical analyses were carried out using the SISVAR ${ }^{\circledR}$ (Ferreira, 1999) statistical software package. A simple correlation analysis was also carried out for DMY, ICF, TDN, CP, NDF, ADF and lignin attributes and the best equations of the ICF with the DMY and the CP were determined by using Excel software.

\section{Results and Discussion}

Dry mass yield (DMY) was influenced by the triple interaction (intercropping $\times$ harvest time $\times$ nitrogen fertilization), although only the TS (Tanzania grass sown simultaneously in the $1^{\text {st }}$ period) did not present any significance whereas the TS in the $2^{\text {nd }}$ and the TC (Tanzania sown together with the cover nitrogen fertilization in the $2^{\text {nd }}$ and $3^{\text {rd }}$ harvest times) presented quadratic regression (Figure 2). The doses of nitrogen which produced the highest DMY levels were 185.42; 176.75 and $148.60 \mathrm{~kg} \mathrm{ha}^{-1}$ yielding 3.978 ; 3.873 and $5.676 \mathrm{kgha}^{-1}$ of dry mass, respectively. 
The remaining interactions presented linear regression in relation to the doses of nitrogen. These results corroborate the reports of Martha Júnior et al. (2007), in which the response of tropical grass pastures to nitrogen fertilizer is significant up to doses of $180 \mathrm{~kg} \mathrm{ha}^{-1}$ of $\mathrm{N}$ per growth cycle. However, according to the results of Martha Júnior et al. (2009), the dry mass yield (DMY) and the nitrogen levels in the Tanzania grass were not influenced by the nitrogen fertilization, which is explained by the decrease in the recovery of the $\mathrm{N}$-urea in the soil-plant system with the increase of the doses in situations of excessive rain, contributing to increased nitrogen losses. However, in the climatic conditions of the present work (Figure 1), nitrogen fertilization was technically viable.

According to Anghinoni (2007), in the first five years of no-tillage system (soil phase of this study), the inittial accumulation of organic matter, phosphorus (P) and straw on the surface and the immobilization of $\mathrm{N}$ approaches that of mineralization. According to Martha Júnior \& Vilela (2007), the principal economic advantage of crop-livestock integration in the livestock phase reflects the increased fertility of the soil (residual effect), which can generally dispense with phosphorus ( $\mathrm{P}$ ) and potassium (K) fertilization in the short term (up to two and a half year) despite of depending on nitrogen fertilization.

Dry mass yield (DMY) values, related to the doses of $\mathrm{N}$ in the intercrops between each harvesting time were similar, although being independent of the dose. TC (Tanzania grass sown along with the cover nitrogen fertilization at the $1^{\text {st }}$ harvesting time) and MS (Mombaça sown simultaneously in the absence of nitrogen fertilization at the $3^{\text {rd }}$ harvesting time) were lower than the others. Because it was not fully established at the moment of uniform cutting, the TC at the first harvesting time was the most harmed intercrop because, in the absence of fertilization, it was the only one that did not attain the $1,200 \mathrm{~kg} \mathrm{ha}^{-1}$ of dry mass estimated by Mott (1980), as the minimum acceptable value for harvesting or bovine
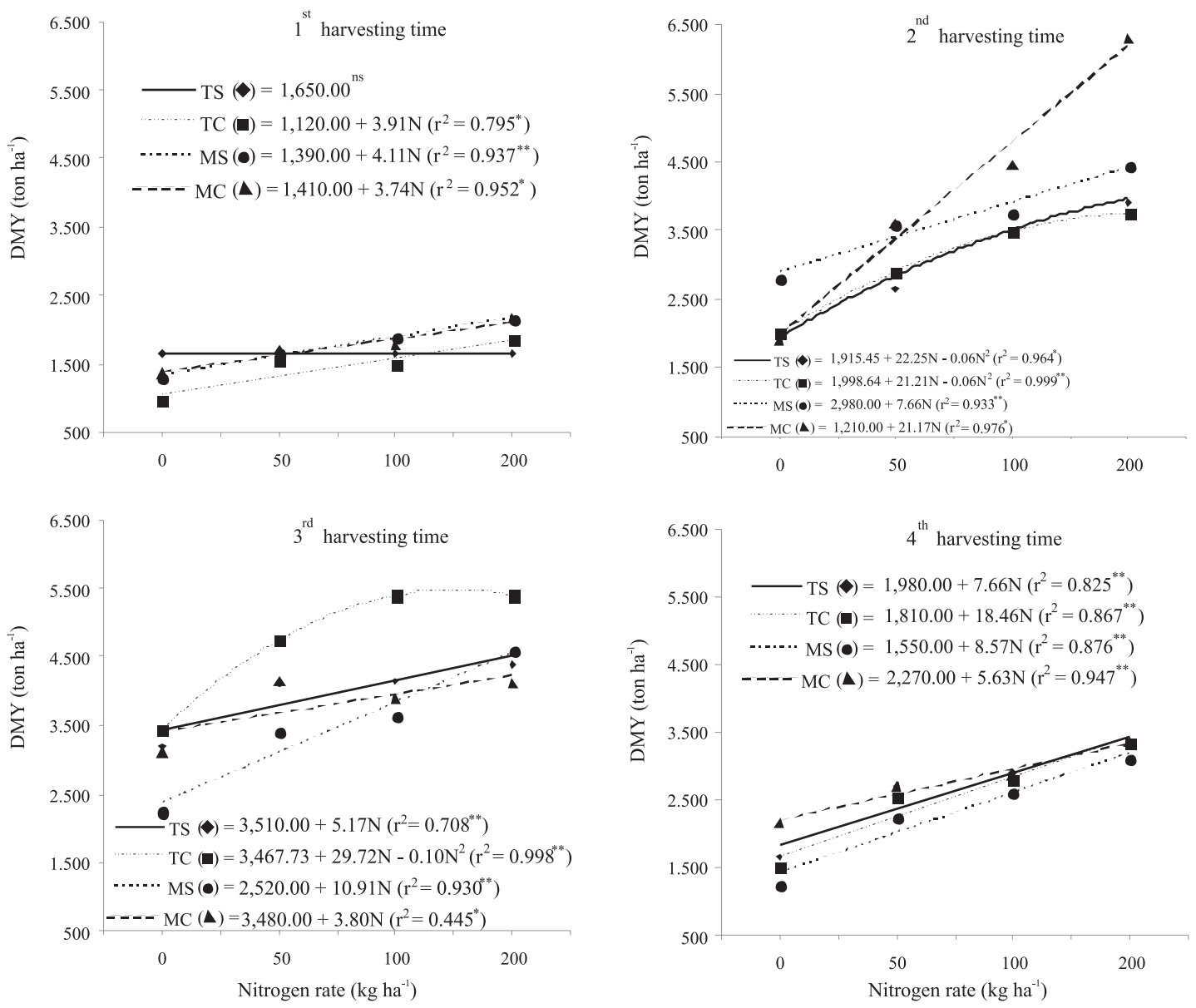

TS: Tanzania grass sown simultaneously with the corn; TC: Tanzania grass sown together with the cover nitrogen fertilization of the corn; MS: Mombaça grass sown simultaneously with the corn; MC: Mombaça grass sown together with the cover nitrogen fertilization of the corn.

**, *, ns: significant to 1 and 5 per cent and non-significant, respectively.

Figure 2 - Dry mass yield (DMY) of Tanzania and Mombaça grasses after the intercropping with corn, harvesting times and nitrogen rates. 
consumption in pasture. Therefore, even in the absence of fertilization with $\mathrm{N}$, the average DMY of the system under study was 2,000 $\mathrm{kg} \mathrm{ha}^{-1}$ at the time of the greatest shortage of forage for the animals (winter/spring).

Müller et al. (2002), when evaluating Mombaça grass, concluded that in the cerrado conditions, the main attributes responsible for its productivity were the minimal air temperature (below $20^{\circ} \mathrm{C}$ ) and soil humidity. Therefore, as these authors suggest, the lower DMY at the $1^{\text {st }}$ harvesting time (early winter) may be attributed to the time required for the recovery of the plants, which may be explained by the low regrowth vigor of the pasture due to the climatic conditions after the uniform harvesting (Figure 1). When daytime temperatures and length of the photoperiod started to increase at the beginning of spring, an increase in DMY occurred and from the $3^{\text {rd }}$ to $4^{\text {th }}$ harvesting time, a decrease in DMY was noted, possibly due to the cutting of the apical buds, which may have hampered the growth of the grass in the subsequent cycle. Therefore, at early spring, it is recommended to increase the cutting height of the Tanzania and Mombaça grasses.

Due to the adverse climatic conditions (low temperature and short photoperiod), Barducci et al. (2009) confirmed that in the edaphoclimatic conditions of Botucatu, State of São Paulo, Mombaça grass intercropped simultaneously with corn did not respond to nitrogen fertilization after the harvest of the grain inasmuch as it was only after the early spring that the plants recovered an expressive profile of their productive potential, something which was not so expressive in the present work which was focused on a cerrado region, where this grass presented even higher values of DMY compared to the Tanzania grass at the $1^{\text {st }}$ and $2^{\text {nd }}$ harvest times.

The relative chlorophyll content (ICF - leaf chlorophyll index) presented an increasing effect related to the doses of $\mathrm{N}$, in which only the MC (Mombaça grass sown together with the cover nitrogen fertilization at the $4^{\text {th }}$ harvesting time) did not present any significance. For the other interactions, similar linear adjustments among the intercrops and the harvest times of the Tanzania and Mombaça grasses were verified (Figure 3).

It was also noted that the effect of the nitrogen doses on the levels of crude protein (CP), and only the TS (Tanzania grass sown simultaneously at the $1^{\text {st }}$ and $4^{\text {th }}$ harvest times) and the TC (Tanzania grass sown along with the cover nitrogen fertilization in the $1^{\text {st }}$ and $2^{\text {nd }}$ harvest times) presented quadratic regression, where the doses of nitrogen which produced the highest levels of CP were 150.00; 125.00; 128.57 and $150.00 \mathrm{~kg} \mathrm{ha}^{-1}$, yielding 22.82; 17.00; 21.31 and $17.74 \%$ of CP, respectively (Figure 3 ).
According to Whitehead (2000), the increase in the yields of CP of $M$. maximum with the increase in the dose of $\mathrm{N}$ may be harmed if the period of regrowth is longer than 28 days. Therefore, the quadratic behaviors may have been influenced by the 30-day cutting interval, because in these cases, the decrease in the intervals could alter this effect inasmuch as the absence of animal trampling, irrigation and the suitable fertility of the soil, allied to the nitrogen fertilization, promote rapid regrowth of the grass after harvesting (Figure 3). Even so, it is important to highlight the raised level of CP in the grasses in the absence of nitrogen fertilization with an average of 12.2 per cent between the intercrops.

According to Manarim \& Monteiro (2003), the highest content of CP in the blades of recently opened leaves of Mombaça grass was 10.31 per cent, corresponding to the SPAD value of 45 units whereas in the case of Aruana grass it was 17.75 and $21.3 \%$ of $C P$ and 49.0 and 42.8 SPAD units, for the $1^{\text {st }}$ and $2^{\text {nd }}$ harvest, respectively, according to Lavres Júnior \& Monteiro (2006). Therefore, in the absence of fertilizer, regardless to intercropping and harvesting time, the levels of CP and ICF were similar to the results in the SPAD unit of Lavres Júnior \& Monteiro (2006) and higher than those of Manarim \& Monteiro (2003) because by the same measurement scale, there may be equivalence among the measurements taken by using both devices. These results prove that the soil in this study afforded some nitrogen supply, possibly due to incipient mineralization of the organic matter, together with a slight immobilization of the residual fertilizer of the corn due to the straw on the soil surface (Anghinoni, 2007).

The other interactions of CP levels displayed linear increment with the doses of $\mathrm{N}$ (Figure 3), where, due to the concentration effect on the dry matter, the highest levels occurred at the $1^{\text {st }}$ harvesting time. Similary to TS (Tanzania grass sown simultaneously at the $2^{\text {nd }}$ and $3^{\text {rd }}$ harvesting time) and the TC (Tanzania grass sown along with the cover nitrogen fertilization in the $3^{\text {rd }}$ and $4^{\text {th }}$ harvesting time), Barros et al. (2002) confirmed linear increases in CP contents in Tanzania grass established by intercropping with pearl millet (Pennisetum glaucum (L.) R. Br.) and fertilized with doses of $\mathrm{N}$. In relation to the intercrops, only at the $1^{\text {st }}$ harvesting time did TS present a slightly higher level of CP compared to the others, although at the subsequent harvest times this performance was not repeated, corroborating Brâncio et al. (2002) and Quadros \& Rodrigues (2006), when they compared strains of M. maximum fertilized with nitrogen. The levels of 9.7 to 22.8 per cent of CP in the present work were satisfactory, given that they were higher than the $7 \%$ considered by 

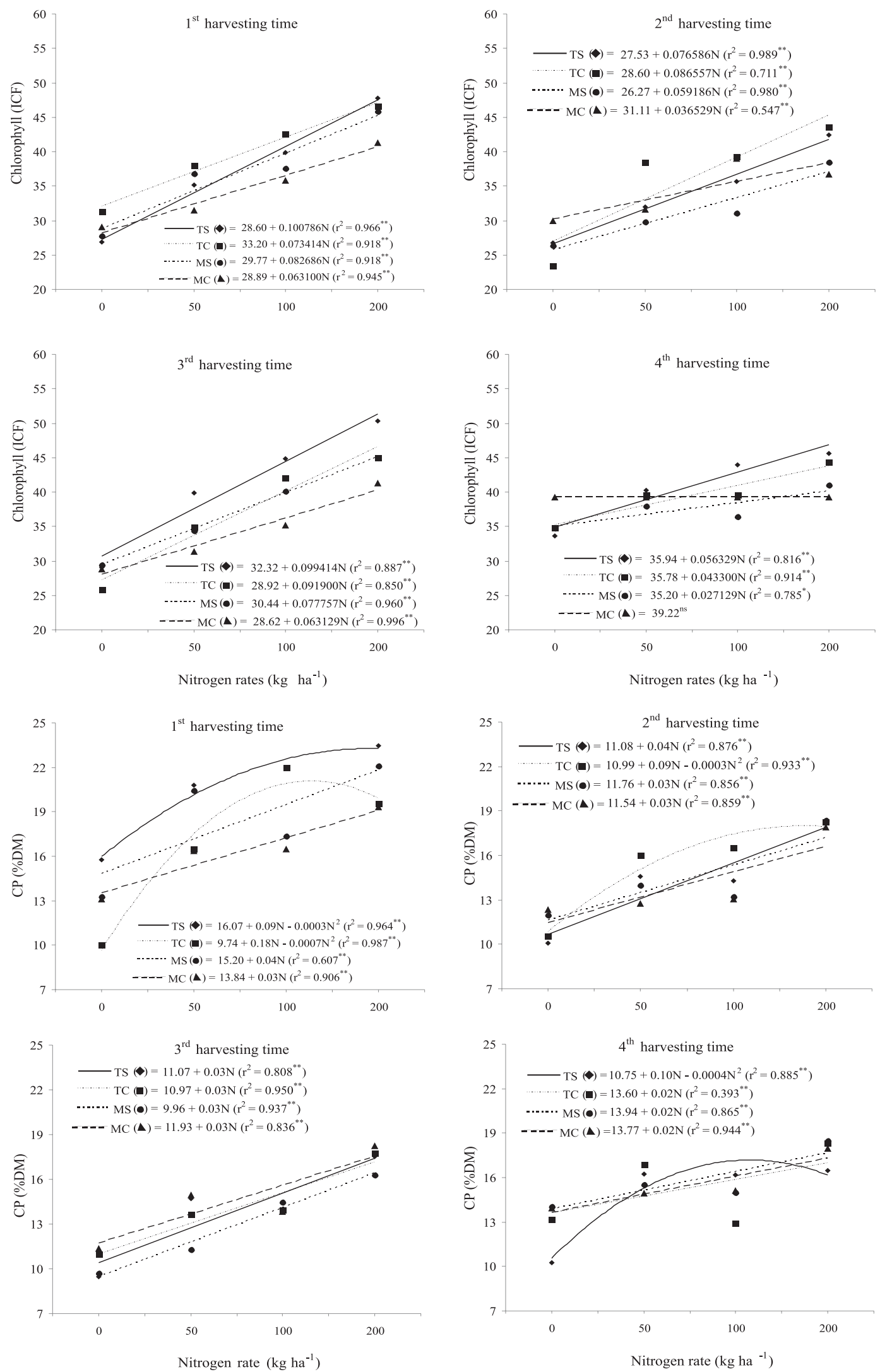

TS: Tanzania grass sown simultaneously with the corn; TC: Tanzania grass sown together with the cover nitrogen fertilization of the corn; MS: Mombaça grass sown simultaneously with the corn; MC: Mombaça grass sown together with the cover nitrogen fertilization of the corn.

**, *, ns: significant to 1 and 5 per cent and non-significant, respectively.

Figure 3 - Relative chlorophyll (ICF - leaf chlorophyll index) and crude protein (CP) contents of Tanzania and Mombaça grasses after intercropping with corn, harvesting times and nitrogen rates. 
Van Soest (1994), as a minimum to maintain the population of microorganisms in bovine rumen.

The increase in the level of CP of pastures occurs up to high doses of $\mathrm{N}\left(800 \mathrm{~kg} \mathrm{ha}^{-1}\right.$ year-1 $\left.^{-1}\right)$, corresponding from 50 to $90 \mathrm{~g}$ of CP kg-1 of dry mass for each $100 \mathrm{~kg} \mathrm{ha}^{-1}$ of $\mathrm{N}$. However, the application of lower doses of $\mathrm{N}$ in the rainy season may have little effect on CP contents, although it increases the growth of the plants (Whitehead, 2000), which is confirmed by the results of the present study inasmuch as the lowest increments of CP related to the doses of $\mathrm{N}$ occurred at the $4^{\text {th }}$ harvesting time (Figure 3 ).

According to Van Soest (1994), the state of maturity of the grass has more influence on neutral detergent fiber (NDF) contents than does the nitrogen fertilization. In the comparison among the intercrops, only at the $1^{\text {st }}$ harvesting time, did the TC( Tanzania grass sown along with the cover nitrogen fertilization) present a higher TDN contents than the others. Given that this was calculated in relation to NDF contents, an increase on contents of TDN occurred with the decrease of NDF contents (Table 1). The concentration effect in the dry matter was also confirmed for these attributes, with the lowest NDF contents and the highest TDN contents verified at the 1 st harvesting time, regardless to the intercropping and to the dose of N. In general, NDF contents were lower than the 74.5 and $73.4 \%$ of the Mombaça grass during the rainy (October to March) and dry season (April to September), respectively, which was reported by Euclides et al. (2008) and lower than the $75.7 \%$ of the Tanzania grass, reported by Difante et al. (2009) whereas TDN contents remained close to the 55\% reported by Van Soest (1994) in tropical forages.

Only at the $4^{\text {th }}$ harvesting time, TDN and NDF contents did not alter significantly as a result of $\mathrm{N}$ doses whereas at the $2^{\text {nd }}$ harvesting time, only NDF presented quadratic regression, when the dose of $\mathrm{N}$ which provided the highest level was $77.86 \mathrm{~kg} \mathrm{ha}^{-1}$, yielding $69.99 \%$ of FDN (Figure 4). The remaining interactions presented linear regression as a result of $\mathrm{N}$ doses, in which, in general, TDN increased and NDF decreased as doses of $\mathrm{N}$ were raised. Except for the $1^{\text {st }}$ harvesting time, the NDF contents were similar to the 70.8 and $70.3 \%$, with and without irrigation, in the dry season, respectively, and lower than 77.4 and $75.3 \%$, with and

Table 1 - Interaction of the average total digestible nutrients (TDN) and neutral detergent fiber (NDF) contents from the intercrop $\times$ $\mathrm{N}$ dose and harvesting times $\times$ nitrogen rates of the Tanzania and Mombaça grasses

\begin{tabular}{|c|c|c|c|c|}
\hline \multirow[b]{2}{*}{ Intercrop } & \multirow[b]{2}{*}{$\mathrm{TS}^{*}$} & \multicolumn{2}{|c|}{ TDN (\%MS) } & \multirow{2}{*}{$\begin{array}{c}\mathrm{CV}=1.6 \% \\
\mathrm{MC}\end{array}$} \\
\hline & & TC & MS & \\
\hline \multicolumn{5}{|l|}{ Harvesting times } \\
\hline $\begin{array}{l}1 \\
2 \\
3 \\
4\end{array}$ & $\begin{array}{l}57.43 \mathrm{bA}^{* *} \\
54.58 \mathrm{aB} \\
54.33 \mathrm{aBC} \\
53.77 \mathrm{aC}\end{array}$ & $\begin{array}{l}58.46 \mathrm{aA} \\
55.41 \mathrm{aB} \\
53.94 \mathrm{aC} \\
54.37 \mathrm{aC}\end{array}$ & $\begin{array}{l}57.51 \mathrm{bA} \\
54.58 \mathrm{aB} \\
53.95 \mathrm{aB} \\
53.80 \mathrm{aB}\end{array}$ & $\begin{array}{l}56.45 \mathrm{cA} \\
55.13 \mathrm{aB} \\
53.67 \mathrm{aC} \\
53.92 \mathrm{aC}\end{array}$ \\
\hline Dose $\left(\mathrm{kg} \mathrm{ha}^{-1}\right.$ of $\left.\mathrm{N}\right)$ & 0 & 50 & 100 & 200 \\
\hline $\begin{array}{l}\text { Harvesting times } \\
1 \\
2 \\
3 \\
4\end{array}$ & $\begin{array}{l}56.77 \mathrm{~A}^{* *} \\
54.87 \mathrm{~B} \\
53.42 \mathrm{C} \\
53.62 \mathrm{C}\end{array}$ & $\begin{array}{l}57.46 \mathrm{~A} \\
54.87 \mathrm{~B} \\
54.00 \mathrm{C} \\
53.79 \mathrm{C}\end{array}$ & $\begin{array}{l}57.43 \mathrm{~A} \\
54.46 \mathrm{~B} \\
53.69 \mathrm{~B} \\
54.31 \mathrm{~B}\end{array}$ & $\begin{array}{c}58.19 \mathrm{~A} \\
55.50 \mathrm{~B} \\
54.78 \mathrm{~B} \\
53.85 \mathrm{C} \\
\mathrm{CV}=2.6 \%\end{array}$ \\
\hline Intercrop & $\mathrm{TS}^{*}$ & TC & MS & MC \\
\hline $\begin{array}{l}\text { Harvesting times } \\
\qquad \begin{array}{l}1 \\
2 \\
3 \\
4\end{array}\end{array}$ & $\begin{array}{l}63.20 \mathrm{bC} C^{* *} \\
70.03 \mathrm{aB} \\
70.64 \mathrm{aB} \\
72.68 \mathrm{aA}\end{array}$ & $\begin{array}{l}60.03 \mathrm{cC} \\
68.05 \mathrm{aB} \\
71.57 \mathrm{aA} \\
71.60 \mathrm{aA}\end{array}$ & $\begin{array}{l}63.00 \mathrm{bC} \\
70.03 \mathrm{aB} \\
71.54 \mathrm{aAB} \\
71.90 \mathrm{aA}\end{array}$ & $\begin{array}{l}65.54 \mathrm{aC} \\
68.72 \mathrm{aB} \\
72.21 \mathrm{aA} \\
71.62 \mathrm{aA}\end{array}$ \\
\hline Dose $\left(\mathrm{kg} \mathrm{ha}^{-1}\right.$ of $\left.\mathrm{N}\right)$ & 0 & 50 & 100 & 200 \\
\hline $\begin{array}{l}\text { Harvesting times } \\
\qquad \begin{array}{l}1 \\
2 \\
3 \\
4\end{array}\end{array}$ & $\begin{array}{l}64.78 \mathrm{~B}^{* *} \\
69.34 \mathrm{~A} \\
72.82 \mathrm{~A} \\
72.34 \mathrm{~A}\end{array}$ & $\begin{array}{l}63.13 \mathrm{C} \\
69.35 \mathrm{~B} \\
71.43 \mathrm{~A} \\
71.94 \mathrm{~A}\end{array}$ & $\begin{array}{l}63.19 \mathrm{C} \\
70.32 \mathrm{~B} \\
72.16 \mathrm{~A} \\
71.75 \mathrm{AB}\end{array}$ & $\begin{array}{l}61.37 \mathrm{D} \\
67.83 \mathrm{C} \\
69.55 \mathrm{~B} \\
71.78 \mathrm{~A}\end{array}$ \\
\hline
\end{tabular}

\footnotetext{
* TS = Tanzania grass sown simultaneously with corn; TC = Tanzania grass sown at time of nitrogen fertilization cover of corn; MS = Mombaça grass sown simultaneously with corn; MC = Mombaça grass sown at time of nitrogen fertilization cover of corn.

** Averages followed by the same lowercase letters on the lines and capital letters on the columns within each evaluation do not differ significantly by the Tukey test at $5 \%$ of probability.
} 
without irrigation, in the rainy season, respectively, confirmed by Ribeiro et al. (2009), on Mombaça grass. Thus, in order to reduce the effect of seasonality, it is possible to increase the cutting interval in the dry season, incidentally raising the DMY, and to diminish this interval in the wet season, to obtain forage with a lower content of fiber and better nutritional value.

Contents of acid detergent fiber (ADF) were not influenced by the doses of $\mathrm{N}$ only at the $4^{\text {th }}$ harvesting time (Figure 5). The TC (Tanzania grass sown along with the cover nitrogen fertilization) and the MC (Mombaça grass sown along with the cover nitrogen fertilization at the $2^{\text {nd }}$ harvesting time) presented quadratic regression when the doses of $\mathrm{N}$ which provided the highest ADF contents were 83.33 and $87.50 \mathrm{~kg} \mathrm{ha}^{-1}$, yielding 36.15 and 38.51 per cent of $\mathrm{ADF}$, respectively. The remaining interactions were in line with the linear regressions in relation to $\mathrm{N}$ doses, with a decrease in ADF occurring as a result of the increase in the doses of $\mathrm{N}$ and at the $1^{\text {st }}$ harvesting time, lower ADF contents occurred only with NDF.

Regardless to lignin, the TS (Tanzania grass sown simultaneously at the $1^{\text {st }}$ harvest time), MC (Mombaça grass sown along with the cover nitrogen fertilization at the $3^{\text {rd }}$ and $4^{\text {th }}$ harvesting times) did not present significant alterations (Figure 5). Whereas TC (Tanzania grass sown along with the cover nitrogen fertilization), MS and MC at the $1^{\text {st }}$, the TS, the TC and the MC at the $2^{\text {nd }}$ and the TC at the $3^{\text {rd }}$ harvesting times presented quadratic regression, in which the doses of $\mathrm{N}$ which provided the lowest lignin contents were $50 ; 100$ and $100 \mathrm{~kg} \mathrm{ha}^{-1}$, yielding 2.19; 1.64 and $1.55 \%$ of lignin, respectively, and the doses of $\mathrm{N}$ which produced the highest lignin contents were 100; 100; 100 and $50.00 \mathrm{~kg} \mathrm{ha}^{-1}$, yielding $3.13 ; 2.95 ; 3.56$ and $2.49 \%$ of lignin respectively. The remaining interactions presented linear regression due to the doses of $\mathrm{N}$, in which an increase occurred in the lignin contents as a result of the increase in the doses of $\mathrm{N}$, except for TC at the $4^{\text {th }}$ harvesting time. In general, the contents were very similar among the harvest times, remaining from 1 to $4 \%$, values which are similar to those of Euclides et al. (2008), with the Massai and Mombaça grasses and to those of Difante et al. (2009), with the Tanzania grass.

The higher the ADF contents, the lower the digestibility, whereas NDF has a negative correlation with forage consumption, considering levels of $40 \%$ of ADF and $60 \%$ of NDF, as limitants of digestibility and consumption respectively (Van Soest, 1994). The NDF contents were higher than 60\% (Table 1; Figure 4), evidencing that Tanzania and Mombaça grasses presented increased NDF contents despite nitrogen fertilization, irrigation, the 30-day cutting interval and the $40 \mathrm{~cm}$ cutting height (a large quantity of leaves). $\mathrm{ADF}$ contents were below $40 \%$, inferring that the forage is of lower consumption but of good digestibility.

In both grasses, the DMY did not reveal significant linear correlation except for the crude protein (CP) (Table 2), which is negative with the TDN, whereas the TDN and the $\mathrm{CP}$ revealed positive correlation between the two, and a negative one with the NDF and the ADF, at the same time that they revealed positive linear correlation between the two of them.

Canto et al. (2008) confirmed that Tanzania grass under continuous stocking until the end of spring at pasture heights from 40 to $60 \mathrm{~cm}$, provided sufficient quantities of leaves and high rates of accumulation of dry mass with restriction of the stems, a factor which improved the chemical composition. Thus, the endeavor of the present work was
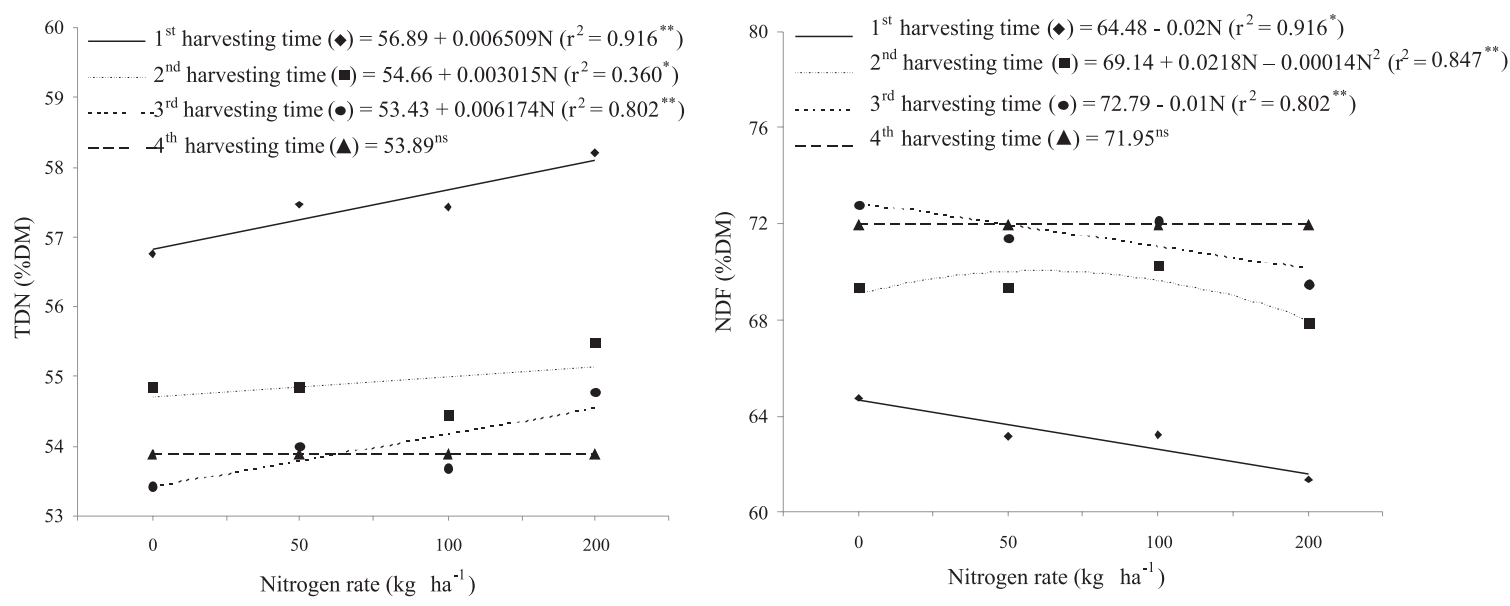

**, *, ns: significant to 1 and 5\% and non-significant, respectively.

Figure 4 - Total digestible nutrients (TDN) and neutral detergent fiber (NDF) contents of the Tanzania and Mombaça grasses under harvesting times and nitrogen rates. 

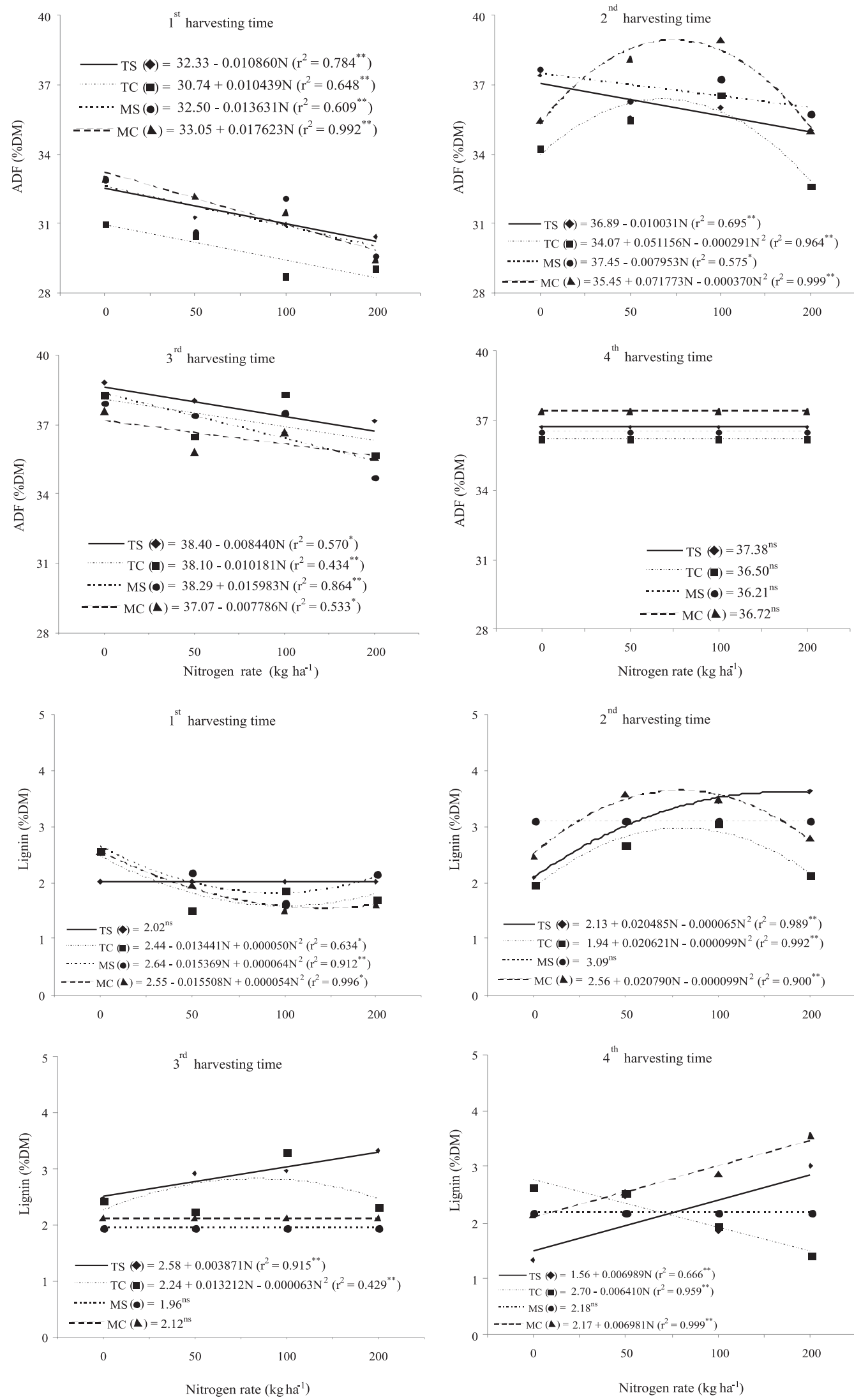

TS = Tanzania grass sown simultaneously with the corn; TC = Tanzania grass sown together with the cover nitrogen fertilization of the corn; MS = Mombaça grass sown simultaneously with the corn; $\mathrm{MC}=$ Mombaça grass sown together with the cover nitrogen fertilization of the corn.

**, *, ns: significant to 1 and $5 \%$ and non-significant, respectively.

Figure 5 - Acid detergent fiber (ADF) and lignin contents of Tanzania and Mombaça grasses after intercropping with corn, harvesting times and nitrogen rates. 
Table 2 - Matrix of linear correlation among the dry mass yield, the relative chlorophyll content (ICF = foliar chlorophyll index) and the chemical composition of Tanzania and Mombaça grasses

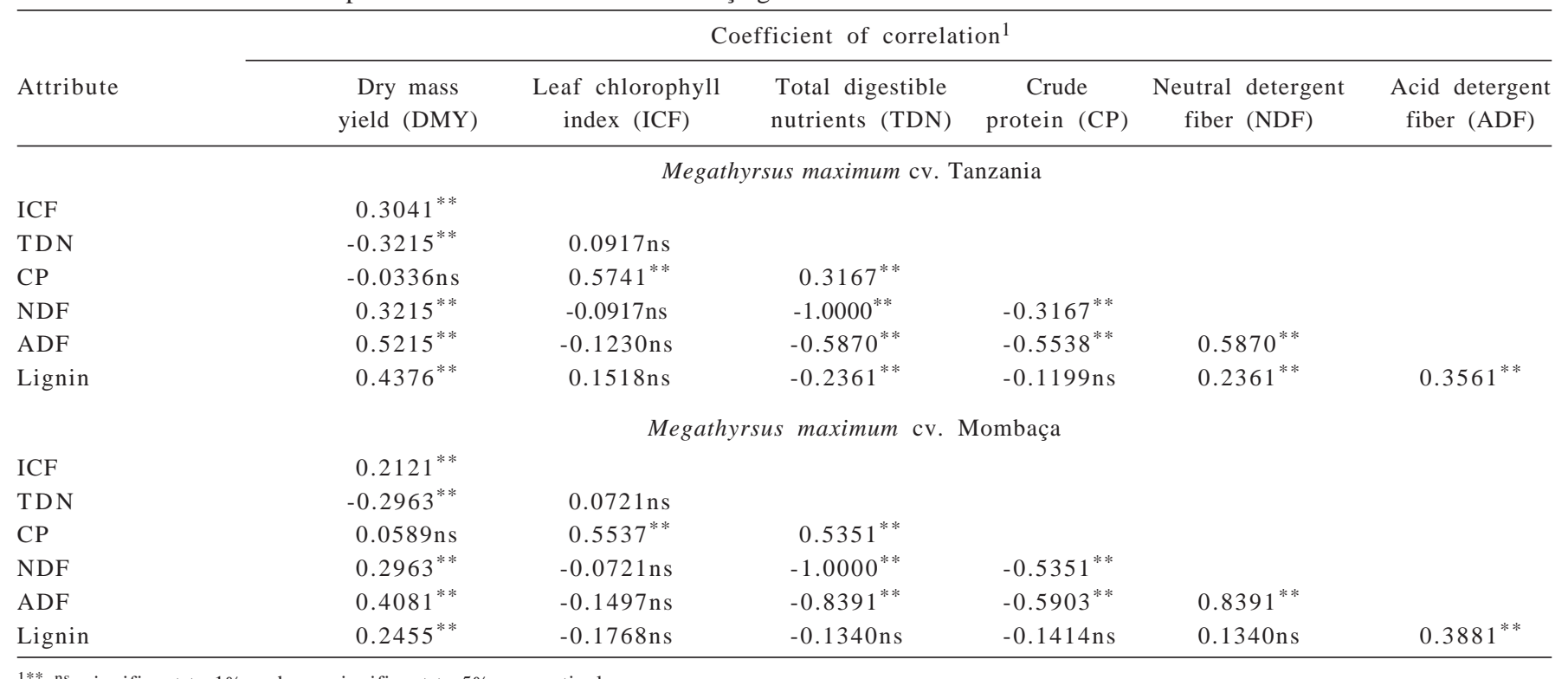

$1 * *$, ns: significant to $1 \%$ and non-significant to $5 \%$, respectively.

to explore these management tools (nitrogen fertilization and height of cutting), in order to obtain a forage of better quality and in a satisfactory quantity.

Rocha et al. (2005) suggested that the relative chlorophyll content may be used as an indicator of nitrogen levels in the plant, in addition to providing a good correlation with the yield of some crops, such as Mombaça grass (Manarim \& Monteiro, 2003) and Aruana grass (Lavres Júnior \& Monteiro, 2006). The increase in the $\mathrm{CP}$ contents with higher doses of $\mathrm{N}$ may be explained by the presence of chlorophyll molecules in protein complexes and they are produced by the plant by the chloroplasts which possess RNA, DNA and ribosomes, thus being capable of synthesizing and multiplying proteins (Maranhão et al., 2009). The positive and high correlation between these attributes is of great importance in the early diagnosis of $\mathrm{N}$ deficiencies, ensuring that decisions are taken in good time for possible cover applications of this nutrient. Due to the high number of observations per grass $(n=128)$, the coefficients of correlation of the ICF with the DMY and the CP are shown to be from poor to moderate ( 0.20 to 0.69 ), nevertheless, significant $(\mathrm{p} \leq 0.01)$ (Table 2$)$.

The equations that presented the highest values of $\mathrm{r}^{2}$ were exponential in the DMY and in the CP of the Tanzania grass and exponential in the DMY and logarithmic in the CP of the Mombaça grass (Figure 6). Determining the ICF using the chlorophyll meter has the advantages of readings not influenced by excessive consumption of $\mathrm{N}$ by the plant and they can be carried
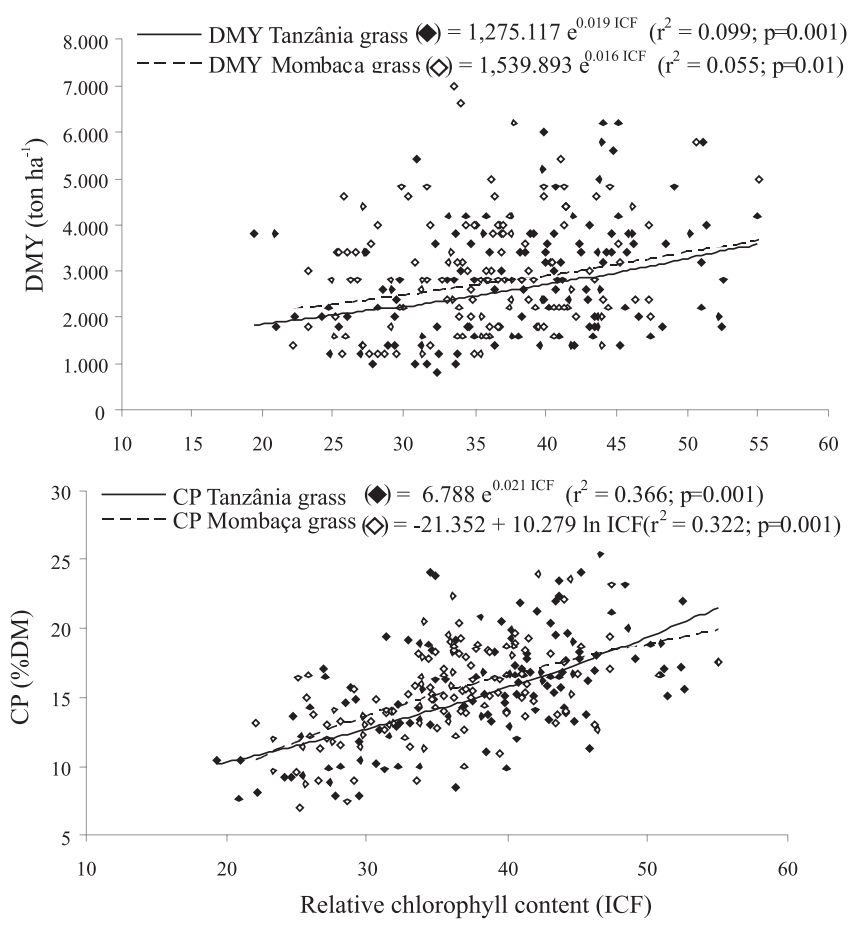

Figure 6 - Relationship between dry mass yield (DMY) and the crude protein (CP) contents with the relative chlorophyll content (IFC = foliar chlorophyll index) of Tanzania and Mombaça grasses (number of observation per grass $=128$ ).

out in a few seconds, enabling a fast diagnosis of the situation of the pasture with an estimate of the DMY and the CP contents, which will also make it easier to determine the need for protein supplementation of the animals if the pasture is designated for grazing. 


\section{Conclusions}

The nitrogen fertilization of Tanzania and Mombaça grasses established in simultaneous intercropping or at the time of cover nitrogen fertilization of the corn crop raises the dry mass yield and the leaf chlorophyll index (ICF) and improves the chemical composition of the grasses in winter/ spring. The index of chlorophyll in the leaf blades may be used as an indicator of the dry mass yield, of the crude protein contents and of the need for nitrogen fertilization of these grasses submitted to harvesting.

\section{References}

AIDAR, H.; RODRIGUES, J.A.S.; KLUTHCOUSKI, J. Uso da integração lavoura-pecuária para produção de forragem na entressafra. In: KLUTHCOUSKI, J.; STONE, L.F.; AIDAR, H. (Eds.) Integração lavoura-pecuária. Santo Antonio de Goiás: Embrapa Arroz e Feijão, 2003. p.225-262.

ANGHINONI, I. Fertilidade do solo e seu manejo em sistema plantio direto. In: NOVAIS, R.F.; ALVARES, V.H.; BARROS, N.F. et al. (Eds.) Fertilidade do solo. Viçosa, MG: SBCS, 2007. p.873-928.

BARDUCCI, R.S; COSTA, C.; CRUSCIOL, C.A.C. et al. Produção de Brachiaria brizantha e Panicum maximum com milho e adubação nitrogenada. Archivos de Zootecnia, v.58, n.222, p.211-222, 2009.

BARROS, C.O.; PINTO, J.C.; EVANGELISTA, A.R. et al. Rendimento e composição química do capim-tanzânia estabelecido com milheto sob três doses de nitrogênio. Ciência e Agrotecnologia, v.26, n.5, p.1068-1075, 2002.

BRÂNCIO, P.A.; NASCIMENTO JÚNIOR, D.; EUCLIDES, V.P. et al. Avaliação de três cultivares de Panicum maximum Jacq. sob pastejo. Composição química e digestibilidade da forragem. Revista Brasileira de Zootecnia, v.31, n.4, p.1605-1613, 2002.

CANTO, M.W.; JOBIM, C.C.; GASPARINO, E. et al. Características do pasto e acúmulo de forragem em capim-tanzânia submetido a alturas de manejo do pasto. Pesquisa Agropecuária Brasileira, v.43, n.3, p.429-435, 2008.

CAPPELLE, E.R.; VALADARES FILHO, S.C.; SILVA, J.F.C. et al. Estimativas do valor energético a partir de características químicas e bromatológicas dos alimentos. Revista Brasileira de Zootecnia, v.30, n.6, p.1837-1856, 2001.

DIFANTE, G.S.; NASCIMENTO JÚNIOR, D.; EUCLIDES, V.P.B. et al. Sward structure and nutritive value of tanzania guineagrass subjected to rotational stocking managements. Revista Brasileira de Zootecnia, v.38, n.1, p.9-19, 2009.

EMBRAPA - EMPRESA BRASILEIRA DE PESQUISA AGROPECUÁRIA. Sistema brasileiro de classificação de solos. Rio de Janeiro: CNPS, 2006. 306p.

EUCLIDES, V.P.B; MACEDO, M.C.M.; ZIMMER, A.H. et al. Avaliação dos capins mombaça e massai sob pastejo. Revista Brasileira de Zootecnia, v.37, n.1, p.18-26, 2008.

FERREIRA, D.F. SISVAR: Sistema de análise de variância. Lavras: UFLA/DEX, 1999.
KLUTHCOUSKI, J.; YOKOYAMA, L.P. Opções de integração lavoura-pecuária. In: KLUTHCOUSKI, J.; STONE, L.F.; AIDAR, H. (Eds.) Integração Lavoura-Pecuária. Santo Antonio de Goiás: Embrapa Arroz e Feijão, 2003. p.131-141.

LAVRES JÚNIOR, J.; MONTEIRO, F.A. Diagnose nutricional de nitrogênio no capim-aruana em condições controladas. Revista Brasileira de Ciência do Solo, v.30, n.5, p.829-837, 2006.

MANARIN, C.A.; MONTEIRO, F.A. Nitrogênio na produção e diagnose foliar do capim-mombaça. Boletim da Indústria Animal, v.59, n.2, p.115-123, 2003.

MARANHÃO, C.M.A.; SILVA, C.C.F.; BONOMO, P. et al. Produção e composição bromatológica de duas cultivares de braquiária adubadas com nitrogênio e sua relação com o índice SPAD. Acta Scientiarum. Animal Science, v.31, n.2, p.117-122, 2009.

MARTHA JÚNIOR, G.B.; CORSI, M.; TRIVELIN, P.C.O. et al. Recuperação de ${ }^{15} \mathrm{~N}$-ureia no sistema solo-planta de pastagem de capim-tanzânia. Revista Brasileira de Ciência do Solo, v.33, n.1, p.95-101, 2009.

MARTHA JÚNIOR, G.B.; VILELA, L. Resultado econômico e estratégias de intensificação da adubação de pastagens. In: MARTHA JÚNIOR, G.B.; VILELA, L.; SOUSA, D.M.G. (Eds.) Uso eficiente de corretivos e fertilizantes em pastagens. Planaltina: Embrapa Cerrados, 2007. p.69-92.

MARTHA JÚNIOR, G.B.; VILELA, L.; SOUSA, D.M.G. Adubação nitrogenada. In: MARTHA JÚNIOR, G.B.; VILELA, L.; SOUSA, D.M.G. (Eds.) Uso eficiente de corretivos e fertilizantes em pastagens. Planaltina: Embrapa Cerrados, 2007. p.117-144.

MOTT, G.O. Measuring forage quantity and quality in grazing trials. In: SOUTHERN PASTURE AND FORAGE CROP IMPROVEMENT CONFERENCE, 37., 1980, Nashville. Anais... Nashville: AESA/ARS, 1980. p.3-9.

MÜLLER, M.S.; FANCELLI, A.L.; DOURADO-NETO, D. et al. Produtividade do Panicum maximum cv. Mombaça irrigado, sob pastejo rotacionado. Scientia Agricola, v.59, n.3, p.427433, 2002.

QUADROS, D.G.; RODRIGUES, L.R.A. Valor nutritivo dos capins Tanzânia e Mombaça adubados com nitrogênio e sob lotação rotacionada. Acta Scientiarum. Animal Science, v.28, n.4, p.385-392, 2006.

RIBEIRO, E.G.; FONTES, C.A.A.; PALIERAQUI, J.G.B. et al. Influência da irrigação, nas épocas seca e chuvosa, na produção e composição química dos capins napier e mombaça em sistema de lotação intermitente. Revista Brasileira de Zootecnia, v.38, n.8, p.1432-1442, 2009.

ROCHA, R.N.C.; GALVÃO, J.C.C.; TEIXEIRA, P.C. et al. Relação do índice SPAD, determinado pelo clorofilômetro, com teor de nitrogênio na folha e rendimento de grãos em três genótipos de milho. Revista Brasileira de Milho e Sorgo, v.4, n.2, p.161-171, 2005.

SILVA, D.J.; QUEIROZ, A.C. Análise de alimentos: métodos químicos e biológicos. Viçosa, MG: UFV, 2002. 235p.

TRACY, B.F.; ZHANG, Y. Soil compaction, corn yield response, and soil nutrient pool dynamics within an integrated croplivestock system in Illinois. Crop Science, v.48, n.3, p.1211-1218, 2008.

VAN SOEST, P.J. Nutritional ecology of the ruminant. New York: Cornell University, 1994. 476p.

WHITEHEAD, D.C. Nutrient element in grassland: soil-plantanimal relationships. Wallingford: CAB International, 2000. $330 \mathrm{p}$. 